IDEA - Studia nad strukturą i rozwojem pojęć filozoficznych $\mathrm{XXVIII/2}$

Białystok 2016

\title{
JÓZEF TARNOWSKI
}

(Gdańsk)

\section{ERNST CASSIRER I NELSON GOODMAN: KONSTRUKTYWNA SIEA SYMBOLIZACJI KULTUROWYCH}

\section{Ernst Cassirer}

Immanuel Kant mógłby w gruncie rzeczy stworzyć taką koncepcję jak Ernst Cassirer, gdyby zadał sobie pytanie: skąd się biorą i jak istnieją kategorie rozumu. Kant jednak takiego pytania nie postawił, a zrobił to dopiero ponad wiek później idący po jego śladach właśnie Cassirer. Odpowiedź generalna Cassirera jest tyleż prosta (złudnie prosta), co oczywista: z kultury. Rzecz jasna kultura nie wzięła się znikąd, jest zbiorowym tworem ludzi, ale kiedy już jest, oddziałuje na jednostki w ich ontogenezie i reprodukuje się z pokolenia na pokolenie, a także zmienia się w wyniku upowszechniania się indywidualnych inicjatyw. A co takiego jest w kulturze istotnego $\mathrm{z}$ epistemologicznego punktu widzenia? To - powiada Cassirer - że dostarcza sposobów rozumienia świata. Rozumienie świata ma więc charakter kulturowy. Przeto myśl usiłująca to zrozumieć, jest epistemologią kulturową. Wbrew więc temu, co sądził Kant, jego kategorie nie są autonomicznymi kategoriami rozumu, lecz są subkategoriami kategorii 
bardziej ogólnych - mówiąc przedmiotowo: są składnikami różnych kulturowych sposobów rozumienia świata.

Czy na pewno rozumienia świata? - pyta Cassirer. Takie sformułowanie zakłada, że istnieje jeden świat sam w sobie (jak u Kanta) oraz wiele sposobów jego rozumienia. Wystarczy wszakże porównać światy religijne i naukowe, żeby dojść do przekonania, że odpowiedź na to pytanie jest negatywna: są to różne światy. Światy religijne przyjmują jako swoje bazowe przekonanie założenie o boskiej celowości (co notabene świadczy o tym, że bierze Cassirer pod uwagę judaizm i religie z niego się wywodzące: chrześcijaństwo przede wszystkim, a nie np. buddyzm). Nauka zaś przyjmuje jako swoje bazowe przekonanie materialistyczny determinizm. Teleologizm i determinizm nie dają się połączyć w jeden spójny sposób rozumienia. Świat religii i świat nauki są więc różnymi światami. Cassirer nie mówi jak pozytywistyczni scjentyści, że pierwszy jest złudzeniem, a tylko drugi jest prawomocny. Konstatuje tylko różnice. Świat religii i świat nauki są różnymi, niewspółmiernymi, konstytuowanymi kulturowo światami, a nie różnymi wersjami tego samego świata. Ani religia, ani nauka nie byłyby możliwe bez języka. Język, jak pisze Cassirer, rozwijał się pod wpływem ewoluujących potrzeb, najpierw bezpośrednio praktycznych, do tego służyły m.in. klasyfikacje przedmiotów, a potem przeszedł powolny proces przechodzenia od nazw konkretów do nazw abstraktów - pojęć i kategorii uniwersalnych, służąc „lepszej orientacji i organizacji naszego postrzeganego świata”. W języku konceptualizowane były mity, będące pierwszą próbą ustalenia chronologicznego porządku rzeczy, z potem religie, i z tego gruntu zrodziło się myślenie historyczne, mające swe prapoczątki u Herodota i Tukidydesa, a rozwinięte do formy „świadomości historycznej” dopiero u Vico i Herdera ${ }^{2}$. Historia jako nauka rózni się od fizyki tym, że fizyka wyjaśnia fakty porządkując je w potrójnym porząaku: przestrzeni i czasu, przyczyny i skutku, zaś historia zajmuje się rozumieniem ludzkiego życia

${ }^{1}$ E. Cassirer, Esej o cztowieku. Wstęp do filozofii kultury, przet. A. Staniewska, Warszawa 1971, s. 230.

${ }^{2}$ Tamże, s. 281-282. 
w porządku chronologicznym. Obie są historycznymi konstruktami kulturowy$\mathrm{mi}^{3}$.

Cassirer szuka innych jeszcze sposobów konstruowania świata. I je znajduje. Świat naszego doświadczenia potocznego jest „rządzony” podobnie jak świat nauki przez zasadę przyczynowości, ale ma ona nieco odmienny charakter. Oparta jest na przekonaniu, że przedmioty są takie, jakie się nam jawią. Że nie tylko kształty i masy, ale i kolory, smaki, zapachy, ciepło, gładkość, szorstkość są cechami przedmiotów. Nauka to oczywiście odrzuca. Pogląd potoczny jest więc realizmem naiwnym, a naukowy - krytycznym. Natomiast w interpretacji sensu ludzkich zachowań pogląd potoczny posługuje się kategorią celowości ludzkich zachowań4.

Świat jest kreowany także przez sztukę. Cassirer szuka uporczywie jakiejś differentia specifica sztuki. To, co o tym pisze, jest jednak ogólnikowe i niekonkretne. Najważniejsze jego stwierdzenia są następujące: „sztuka jest prawdziwym objawieniem naszego życia wewnętrznego”, a „sztuki plastyczne sprawiają, że widzimy świat dostępny zmysłom w całym jego bogactwie i różnorodności”, „sztuka pomaga nam dostrzec fomy rzeczy” nie będąc ani kopią natury ani ormamentem życia, a podobnie jak nauka pełni ważną funkcję kognitywną̧. Nasuwa się od razu pytanie, jaką dziedzinę sztuki miał na myśli Cassirer modelując na niej swoje poglądy na temat sztuki w ogóle. Nietrudno jest na to pytanie odpowiedzieć - na iluzyjnym, realistycznym malarstwie renesansowym i kontuynuującym je malarstwie nowożytnym aż do impresjonizmu, ale z jego wyłączeniem, a przynajmniej fazy późnej, w której szkicowość i „plamiastość” niemal uniemożliwiają tworzenie się u widza iluzji fragmentu świata rzeczywistego ${ }^{6}$.

Konkluzja Cassirera jest więc taka, że nie żyjemy w jednym, a zarazem różnie rozumianym świecie, lecz $\mathrm{w}$ różnych niewspółmiernych światach kreowanych przez kulturowe sposoby rozumienia, które nazywa „formami symbolicz-

${ }^{3}$ Tamże, s. 296-297.

${ }^{4}$ Tamże, s. 145, 278.

${ }^{5}$ Tamże, s. 276-278.

${ }^{6}$ Zwracali na to uwagę już współcześni krytycy impresjonizmu, np. Emil Zola, a u nas Wojciech Gerson. Zob. J. Tarnowski, Wielki przetom: studium z estetyki Stanistawa Witkiewicza, Gdańsk 2014, s. 80, 243. 
nymi” (symbolische Formen). Wyodrębnia siedem owych form symbolicznych: język, myślenie potoczne, mit, religę, historię, naukę i sztukę.

Czy pogląd Cassirera daje się obronić? W takiej postaci, w jakiej Cassirer go zwerbalizował, jest nadmiernie zgrubny. Nie bierze pod uwagę na przykład różnic między religiami. Niewspółmierne ze sobą są nie tylko religia en block i nauka en block albo religie między sobą, np. przyjmujące boga osobowego i go nie przyjmujące. Także w obrębie tych pierwszych występuą niedające się zniwelować niewspółmierności. Na przykład nie do pogodzenia jest protestancka wiara $\mathrm{w}$ predestynację $\mathrm{z}$ katolicką wiarą $\mathrm{w}$ wolną wolę $\mathrm{i}$ sąd ostateczny nad uczynkami z niej wypływającymi. Nauki też się między sobą różnią, zarówno generalnie (metaparadygmatycznie), np. nauki przyrodnicze i humanistyczne, jak i paradygmatycznie. W fizyce na przykład teoria kurpuskularna i teoria falowa są odrębnymi, niekompatybilnymi teoriami, a nie dwoma wariantami jednej teorii. W naukach humanistycznych na przykład lingwistyka transformacyjnogeneratywna jest nikompatybilna z kognitywistyczną. Twórcy tego drugiego paradygmatu - np. Mark Johnson, George Lakoff, Mark Turner, Eleanor Rosch pokazali, że i język potoczny kreuje ogrom światów budowanych na różnych schematach metaforyzacyjnych, więc nie daje się zamknąc w jednej „formie symbolicznej"

Jeszcze trudniej byłoby obronić pogląd Cassirera na temat do sztuki. Co pisarz to inny świat; nawet dzieła jednego pisarza mogą się zasadniczo różnić pod względem wykreowanych $w$ nich wizjach świata. Sprawa się jeszcze bardziej komplikuje w przypadku malarstwa, muzyki instrumentalnej, baletu i innych sztuk niereferncjalnych. Młody Panofsky usiłował dopowiedzieć Cassirera w sprawie kreatywnego (a nie odtwórczego) charakteru perspektywy malarskiej, ale jego dziełko na ten temat było zbyt niejasne, aby wywołać coś więcej niż dyskusję

\footnotetext{
${ }^{7} \mathrm{Na}$ polskim rynku dostępna jest tylko jedna, ale bardzo ważna praca reprezentująca ten paradygmat: Georg Lakoff i Mark Johnson, Metafory w naszym życiu, przeł. T. P. Krzeszowski, Warszawa 1988.

${ }^{8}$ Zob. G. Jurkowlaniec, Wstęp do wydania polskiego, [w:] E. Panofsky, Perspektywa jako ,forma symboliczna", Warszawa 2008, s. 15.
} 
O filozofii Cassirera można orzec to samo, co Cassirer napisał o filozofii Hipolita Taine’a, że więcej obiecuje niż daje ${ }^{9}$. Myśląc o kulturze po Cassirerowsku, trzeba porzucić jego typologię form symbolicznych na rzecz radykalnego pluralizmu kulturowo-epistemologicznego. I tak właśnie uczynił Nelson Goodman. Nie polemizował z nim. Powołał się na niego, oddał mu honory i poszedł swoją drogą - radykalnie pluralistyczną i zarazem konstruktywistyczną.

\section{Nelson Goodman}

Swojego metaepistemologicznego powinowactwa z Cassirerem Goodman nie ukrywał. Przywołał go już w pierwszym zdaniu książki Ways of Worldmaking:

Niezliczone światy tworzone z niczego przez użycie symboli - tak mógłby satyryk streścić niektóre główne tematy w dziele Ernsta Cassirera. Tematy te: wielość światów, zwodnioczość 'danych', kreatywna siła rozumienia oraz różnorodność i formatywna rola symboli - są także integralnymi tematami mojego myślenia. ${ }^{10}$

Goodman przejął od Cassirera jego główną idę̨, iż systemy symboliczne kreują ontologicznie (nie fizycznie) różne światy, a ponieważ istnieje wiele systemów symbolicznych, przeto istnieje (kulturowo) wiele „światowersji” (worldversions $)^{11}$. Nie wdawał się przy tym Goodman ani $\mathrm{w}$ ocenę, ani $\mathrm{w}$ polemikę z Cassirerowską typologią form symbolicznych. Powód jest oczywisty: w każdej $\mathrm{z}$ wyodrębnionych przez Cassirera dziedzin kultury istnieje wiele niekompatybilnych ze sobą wizji czy wersji świata. A więc i światów, bo wizja świata ontologizuje to, do czego się odnosi. A ponieważ nie ma bezpośredniego dostępu poznawczego do świata samego $\mathrm{w}$ sobie (world-in-themselve), to cokolwiek o świecie się orzeka, czyni się to przez symbole stanowiące nośnik jakiejś wizji świata. Inaczej mówiąc - nie ma dostępu do niezinterpretowanych danych,

\footnotetext{
${ }^{9}$ E. Cassirer, dz. cyt., s. 129.

${ }^{10}$ N. Goodman, Ways of Worldmaking, Indianapolis, Cambrigde 1981, s. 1.

${ }^{11}$ Tamże, s. 4, 112.
} 
przeto nie istnieje uniwersalna metoda stwierdzania prawdziwości, która pozwoliłaby na odrzucenie wizji fałszywych i pozostawienie prawdziwych. Prawda jest kategorią wewnątrzsystemową, a nie ponadsystemową. Można trafne orzec, że dane zdanie jest prawdziwe w danym systemie (wersji świata), ale nie, że jest w ogóle prawdziwe. Goodman ilustruje to przykładem zdań: „Ziemia krąży wokół Słońca” i „Słońce krąży wokół Ziemi”. Są sprzeczne, więc nie mogą być oba prawdziwe „w ogóle”. Pierwsze jest prawdziwe w koncepcji heliocentrycznej i pochodnych, drugie w geocentrycznej i w poglądzie potocznym, albowiem nie obserwujemy krążenia wokół Słońca, lecz krążenie Słońca wokoło nas ${ }^{12}$. Każda z nauk przyrodniczych i humanistycznych produkuje własne, wzajemnie niekompatybilne światowersje, a i w obrębie każdej z nich mogą funkcjonować niekompatybilne ze sobą wersje. W „światotwórstwie” uczestniczą nie tylko systemy językowe, składające się z zespołów symboli posiadających wartość logiczną (w obrębie danego systemu), ale i obrazowe, które wartości logicznej nie posiadają, a są także niekompatybilne, jak np. wizje obrazowe Canaletta i van Gogha. Wszystkie one są wzajemnie nieprzekładalne. Problem z kategorią prawdy komplikuje się dodatkowo, jeśli uwzględni się konstatacje fałszywe literalnie, a prawdziwe metaforycznie (oczywiście $\mathrm{w}$ danej światowersji) ${ }^{13}$. $\mathrm{Na}$ pytanie, z czego zrobione są światy (światowersje), Goodman odpowiada: nie z niczego, lecz $z$ innych, wcześniejszych światów (światowersji) - przez ich przetwarzanie $^{14}$.

Do tego miejsca logiczna budowa filozofii Goodmana jest właściwie tylko modyfikacją filozofii Cassirera, przy czym owa modyfikacja polega na radykalizacji epistemologicznego pluralizmu ${ }^{15}$. Zasadnicze różnice między nimi pojawiają się w obszarze semiotyki. Cassirer wpisuje się w tradycję FregowskoPeirce'owską, zgodnie z którą symbolizacja jest relacją triadyczną pomiędzy nośnikiem (symbolem), znaczeniem i przedmiotem odniesienia. Goodman porzu-

${ }^{12}$ Tamże, s. 93.

${ }^{13}$ Tamże, s. 18.

${ }^{14}$ Tamże, s. 6.

${ }^{15} \mathrm{Z}$ perspektywy Kuhn'owskiej można tę różnicę ująć jeszcze tak: Goodmana światowersje są paradygmatami, a Cassirera formy symboliczne - metaparadygmatami. 
ca tę tradycję na rzecz semiotyki nominalistycznej, zgodnie z którą symbolizacja jest relacją diadyczną pomiędzy symbolem, zwanym przezeń „etykietą” (label) i tym, do czego się odnosi. Wyróżnia dwa rodzaje symbolizacji: denotację i egzemplifikację. Denotacja jest odniesieniem etykiety do tego, do czego się ona odnosi. Subkategoriami kategorii denotacji są deskrypcja, gdy etykieta jest językowa, oraz reprezentacja, w przypadku etykiety obrazowej. Subkategoriami kategorii reprezentacji są depikacja, gdy etykietą jest obraz gęsty sematycznie, np pejzaż czy potret, oraz denotajca diagramowa (schematyczna), gdy etykietą jest obraz rzadki sematycznie, np. diagram lub mapa. $Z$ kolei egzemplifikacja jest relacją symbolu jako próbki (sample) do etykiety językowej lub niejęzykowej, która tę próbkę denotuje. Zarówno denotacja, jak i egzemplifikacja może być literalna i metaforyczna. Na przykład etykieta „krawat” denotuje dany krawat literalnie, a etykieta „krzykliwy” może go denotować metaforycznie. Krawiecka próbka materiału egzemplifikuje literalnie teksturę, kolorystykę, wzór i inne cechy całości materiału, a czarna plama na obrazie egzemplifikuje literalnie etykietę ,czarna plama”, natomiast rysunek konia egzemplifikuje metaforycznie etykietę „ruch”, etc. Ezgemplifikację metaforyczną Goodman określa także mianem „ekspresji”. Swoją typologię krótko rekapituluje w Languages of Art:

Chociaż egzemplifikacja i ekspresja różnią się od reprezentacji i deskrypcji tym, że zmierzają w odwrotnym kierunku, to wszystkie te relacja są ściśle ze sobą powiązanymi sposobami symbolizacji. [...] Reprezentacja i deskrypcja odnoszą symbol do etykiety, która go denotuje, i stąd pośrednio do rzeczy [...] objętych zakresem danej etykiety. Ekspresja odnosi symbol do etykiety, która go metaforycznie denotuje, i stąd pośrednio nie tylko do danego metaforycznego, ale i literalnego zakresu etykiety. ${ }^{16}$

Goodmana koncepcja funkcji symbolicznych jest werbalnie częściowo zgodna z tradycyjną logiką języka i uzusem potocznym, a częściowo nie. Gdy mówimy, że kawałek materiału jest próbką materiału lub że „człowiek” jest

${ }^{16}$ N. Goodman, Languages of Art: an Approach to a Theory of Symbols, Indianapolis, Cambridge 1988, s. 92. Pierwsze wydanie tej książki ukazało się w roku 1968. 
przykładem wyrazu „słowo”, to w każdym w tych dyskursów mamy do czynienia z egzemplifikacją. Gdy zaś odnosimy słowo „człowiek” do osoby nazywającej się Nelson Goodman, to mamy do czynienia z denotracją. Jednakże w przypadku reprezentacji rozstrzygnięcia Goodmana naruszają częściowo ustalony dyskurs. Mówiąc, że dany obraz przedstawia kobietę nie zakładamy jej realnego istnienia. Analogicznie jest w przypadku deskrypcji. Mówiąc, że dane słowa opisują mężczyznę, nie zakładamy jego realnego istnienia. Natomiast w koncepcji Goodmana deskrypcja i reprezentacja są odmianami denotacji. Innym odstępstwem od tradycji jest ujęcie egzemplifikacji jako podrelacji odwrotności denotacji. Jeśli przyjmujemy zgodnie z tradycją, że tym, co może być egzemplifikowane są własności, to nie jest możliwe, aby to, co egzemplifikowane denotowało symbol egzemplifikujący, jako że własności nie mogą niczego denotowć. Tymczasem w koncepcji Goodmana mogą. Egzemplifikowane własności są sprowadzalne do etykiet werbalnych nawet jeśli w języku nie ma odpowiedniego terminu denotującego daną próbkę, albowiem z próbki $P$ można utworzyć etykietę „x takie jak $P$ " denotującą próbkę $P$. Nie tylko symbole obrazowe i językowe, ale także dźwięki, gesty i miny mogą być nośnikami denotacji lub egzemplifikacji. $\mathrm{Na}$ przykład gesty dyrygenta denotują dźwięki, jakie mają być wyprodukowane przez orkiestrę, a choć nie są dźwiękami, mogą egzemplifikować pewne własności dźwięków, np. rytm czy tempo. W przeciwieństwie do dyrygenta, instruktor gimnastyczny pokazuje próbki egzemplifikujące wymagane własności ćwiczeń. Z kolei gesty i mimika w pantomimie denotują rzeczywiste czynności i gesty wykonywane przez ludzi w życiu, jednakże nie denotują samych siebie, ponieważ nie są tego typu rzeczywistymi zachowaniami. Na przykład mim może denotować wchodzenie po drabinie i zarazem egzemplifikować czynności składające się na rzeczywiste wchodzenie po drabinie. Pewne elementy denotujące można znaleźć takżę w tańcu, np. gesty codziennego życia, jak pokłony, lub rytuału, jak gesty błogoisławieństwa, inne natomiast, szczególnie w tańcu nowoczesnym, nie denotują niczego, egzemplifikują natomiast rytm i dynamikę ${ }^{17}$.

${ }^{17}$ Tamże, s. 62-65. 
Praktyczna identyfikacja relacji symbolicznych w tej koncepcji nie zawsze jest łatwa i jednoznaczna, co przyznaje sam Goodman pisząc, że w pewnych przypadkach nie można ustalić, czy dana symbolizacja jest denotacją czy egzemplifikacją, przeto identyfikacja musi być arbitralna. Eksplikacja kategorii funkcji symbolicznych w języku nominalistycznym, nieodwołującym się do kategorii znaczenia, bardzo się komplikuje w przypadku symboli z zerową denotacją, np. nazw pustych lub obrazów nieistniejących obiektów. Napis „centaur” lub obraz centaura nie denotują niczego, egzemplifikują natomiast bycie centaurodeskrypcją lub centautro-obrazem. Chociaż deskrypcja i reprezentacja są odmianami denotacji, to deskrypcja-jako i reprezentacja-jako są bliższe egzemplifikacji niż denotacji ${ }^{18}$.

Symbolizacja może być bezpośrednia, gdy symbol odnosi się wprost do tego, co symbolizuje, jak w przytoczonych przykładach, lub pośrednia, gdy odniesienie symbolu do tego, co symbolizowane przebiega przez szereg relacji referencjalnych. Przykładem takiej złożonej symbolizacji jest aluzja, jakże często stosowana $\mathrm{w}$ dyskursach potocznych $\mathrm{i}$ artystycznych i na ogół nie sprawiająca kłopotów ani w praktyce komunikacyjnej, ani w interpretacjach dokonywanych przez tradycyjną poetykę zakładającą triadyczną koncepcję semiotyczną. Możliwość nominalistycznej reiterpretacji aluzji pokazała na kilku przykładach $\mathrm{Ca}^{-}$ therine Elgin w bazującej na koncepcji Goodmana książce With Reference to Reference (1983). Najprostsze warianty aluzji Elgin definiuje następująco: „a jest aluzją wobec $b$ przez denotowanie jakiegoś $c$, które egzemplifikuje $b$ ” lub „a jest aluzją wobec $b$ przez egzemlifikowanie jakiegoś $c$, które denotuje $b$ ". I dodaje, że w tym drugim wariancie aluzji często $c$ nie tylko denotuje $b$, ale także jest przezeń egzemplifikowane ${ }^{19}$. Takie złożone symbolizacje określa Elgin mianem „łańcucha referencjalnego” (chain od reference). Jednym z analizowanych przykładów jest nazwanie jakiegoś rozbudowanego i skomplikowanego dzieła filozoficznego mianem „heglowskiego” (Hegelian). Symbolizacja przez taką aluzję przebiega następująco: etykieta ta denotuje literalnie dzieła filozoficzne Hegla,

${ }^{18}$ Tamże, s. 79.

${ }^{19}$ C. Z. Elgin, With Reference to Reference, Indianapolis, Cambridge 1983, s. 142. Notabene, wstęp do tej książki napisał Goodman. 
które z kolei egzemplifikują etykietę „wielkie rozmiarem i stopniem komplikacji”, która z kolei denotuje dane dzieło, do którego ta aluzja się odnosi ${ }^{20}$. Innym, bardziej złożonym przykładem symbolizacji przez łańcuch referencjalny, jest nazwanie Traktatu Hume'a mianem „kopalni złota”. Etykieta ta denotuje literalnie kopalnie złota, które z kolei egzemplifikują literalnie etykietę „przynoszące korzyść", która jest metaforycznie egzemplifikowana przez wskazane dzieło Hume'a ${ }^{21}$. Nazwanie Traktatu Huméa „kopalnią złota” jest więc symbolizacją pośrednią, realizowaną przez łańcuch referencjalny składający się z trzech ogniw.

Sam Nelson Goodman w wydanej w 1988 roku książce Reconceptions in Philosophy and other Arts and Sciences, napisanej wspólnie z Catherine Elgin, także bierze na warsztat symbolizację złożoną, modyfikując nieco określenie używane przez Elgin - nazywa ją „łańcuchem elementarnych ogniw referencjalnych" (chain of elementary referential links) ${ }^{22}$. Analizuje tam dwa przykłady takich łańcuchów. Pewien kościół reprezentuje statek żaglowy, statek żaglowy egzemplifikuje uwolnienie od lądu, zaś uwolnienie od lądu egzemplifikuje (metaforycznie) duchowość, więc kościół ten odnosi się do uduchowienia przez łańcuch złożony z trzech ogniw. Goodman dodaje, że symbol, który odnosi się do rzeczy przez łańcuch referencjalny, może także odnosić się do niej bezpośrednio ${ }^{23} . \mathrm{Na}$ przykład jakiś budynek czyni aluzję do greckiej świątyni, która z kolei egzemplifikuje klasyczne proporcje, których on sam nie posiada, ale może wyrażać te proporcje bezpośrednio. Inny przykład Goodmana: „fragmenty budynku Michaela Gravesa mogą egzemplifikować kamień zwornikowy i inne formy depiktowane lub egzemplifikowane przez egipską lub grecką architekturę, więc niebezpośrednio odnoszą się do takich budynków oraz z kolei do własności, które one egzemplifikują i wyrażają"24.

${ }^{20}$ Tamże, s. 143.

${ }^{21}$ Tamże, s. 147.

${ }^{22}$ N. Goodman, How Buildings Mean, [w:] N. Goodman i C.Z. Elgin, Reconceptions in Philosophy and other Arts and Sciences, London 1988, s. 42. Notabene, Goodman jest autorem pięciu rozdziałów tej książki, Elgin - trzech, a dwa są ich wspólnego autorstwa.

${ }^{23}$ Tamże, s. 43.

${ }^{24}$ Tamże. Nie ulega wątpliwości, że Goodmanowi idzie o oddany do użytku w 1982 roku budynek władz miejskich w Portland - Portland Municipal Services Building. 
Na pobieżnym przeanalizowaniu tych przypadków Goodman poprzestaje, a dalszych przykładów każe czytelnikom szukać samodzielnie ${ }^{25}$. Sprawa nie jest jednak ani prosta, ani oczywista. Sądzę, że czytelnik ma raczej prawo czekiwać, że autor tak rewolucyjnej koncepcji sam wykaże jej siłę kognitywną. Nie chcę przesądzać o jej potencjale w tym zakresie. W moim przekonaniu semiotyka Goodmana należy, podobnie jak reizm Tadeusza Kotarbińskiego, do heroicznych dokonań filozoficznych, ale wedle mojej wiedzy nie wyszła w gruncie rzeczy z fazy wstępnej.

\title{
ERNST CASSIRER AND NELSON GOODMAN: CONSTRUCTIVE POWER OF CULTURAL SYMBOLISATIONS
}

\author{
Summary
}

According to Ernst Cassirer's views expressed in Philosophy of Symbolic Forms and Essay on Man a man is 'a symbolic animal', which means that: /1/ every meaning is symbolic, /2/ symbolisation creates the world but it does not reflect it, /3/ symbolisations are not individual but cultural, /4/ culture consists of 'symbolic forms', i.e., science, common sense, religion, magic, language and art, which create the world in different ways. Nelson Goodman in Languages of Art and Ways of Worldmaking developed Cassirer's view towards more radical epistemological pluralism and changed his semiotic assumption. Cassirer accepted Frege's understanding of symbolisation as a relation between three elements: a symbol, its meaning and a denoted object. For Goodman symbolisation is a two-element relation: between a symbol and an object, without the category of meaning. Symbols can denote or exemplify or refer to objects in complex and indirect ways. The paper aims to address the problem of the efficiency of that categorisation.

Key words: categorisation, denotation, exemplification, expression, symbol, symbolisation, meaning

Słowa kluczowe: denotacja, egzemplifikacja, ekspresja, kategoryzacja, symbol, symbolizacja, znaczenie

25 „The reader will find his own examples”, tamże. 


\section{Bibliografia}

Cassirer E., Esej o cztowieku. Wstęp do filozofii kultury, przeł. A. Staniewska, Warszawa 1971.

Elgin C. Z, With Reference to Reference, Indianapolis, Cambridge 1983.

Goodman N., Languages of Art: an Approach to a Theory of Symbols, Indianapolis, Cambridge 1988.

Goodman N., Ways of Worldmaking, Indianapolis, Cambrigde 1981

Goodman N., i C.Z. Elgin, Reconceptions in Philosophy and other Arts and Sciences, London 1988.

Jurkowlaniec J., Wstęp do wydania polskiego, w: E. Panofsky, Perspektywa jako ,forma symboliczna”, przeł. J. Jurkowlaniec, Warszawa 2008.

Lakoff G. i M. Johnson, Metafory w naszym życiu, przeł. T. P. Krzeszowski, Warszawa 1988.

Tarnowski J., Wielki przetom: studium z estetyki Stanistawa Witkiewicza, Gdańsk 2014.

dr hab. Józef Tarnowski

Uniwersytet Gdański 